\title{
PENGARUH KESADARAN MEREK DAN PROMOSI TERHADAP KEPUTUSAN KONSUMEN UNTUK MEMBELI DI CV.PANDA BAKERY
}

\author{
Andriasan Sudarso ${ }^{1}$, Maryani Erlic ${ }^{2}$ \\ ${ }^{1}$ Dosen Tetap Sekolah Tinggi Ilmu Ekonomi IBBI Medan \\ andriasans@gmail.com \\ ${ }^{2}$ Program Studi Manajemen Sekolah Tinggi Ilmu Ekonomi IBBI Medan
}

\begin{abstract}
Abstrak
Tujuan dari penelitian ini adalah mengetahui bagaimana pengaruh kesadaran merek dan promosi terhadap keputusan konsumen untuk membeli di CV.Panda Bakery.Jenis penelitian yang digunakan dalam penelitian ini adalah penelitian deskriptif kuantitatif, dengan jenis dan sumber data yang digunakan adalah data primer dan data sekunder. Teknik pengumpulan data yang digunakan adalah dengan wawancara, memberikan daftar pertanyaan (kuesioner). Metode analisis data yang digunakan adalah regresi linear berganda. Populasi dalam penelitian ini adalah seluruh total pelanggan toko pada CV.Panda Bakery yang berjumlah 80 toko. Jumlah sampel dalam penelitian ini menggunakan sampel jenuh karena populasi kurang dari 100, maka jumlah sampel sebanyak 80 toko.

Hasil penelitian menunjukkan bahwa secara bersama-sama variabel bebas mempengaruhi variabel terikat. Hal ini ditunjukkan oleh nilai $\mathrm{F}_{\text {hitung }}>\mathrm{F}_{\text {tabel }}$ yaitu 42,557> 3,115 sehingga $\mathrm{H}_{0}$ ditolak. Hasil

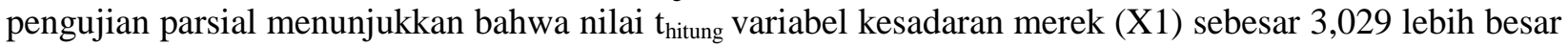

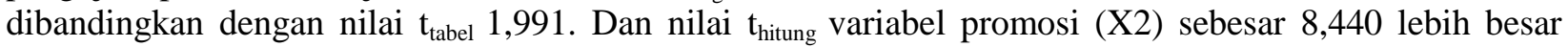
dibandingkan dengan nilai $\mathrm{t}_{\text {tabel }} 1,991$. Maka dalam hal ini secara parsial bahwa variabel kesadaran merek dan promosi berpengaruh terhadap keputusan konsumen.

Kata kunci : Kesadaran Merek, Promosi, Keputusan Konsumen.
\end{abstract}

\section{PENDAHULUAN}

CV.Panda Bakery adalah suatu perusahaan yang bergerak di bidang bakery. Pada masa kini, meskipun sudah banyak berbagai jenis makanan yang diciptakan dan dikonsumsi oleh manusia, tetapi roti masih menjadi salah satu makanan yang dipilih oleh manusia untuk dimakan. Saat ini roti sudah menjadi bagian dari kehidupan sehari-hari. 
CV.Panda Bakery mengalami penurunan jumlah konsumen karena konsumen tidak memiliki kesadaran merek yang tinggi. Kesadaran merek merupakan kemampuan seorang konsumen untuk mengidentifikasi suatu merek (baik mengenal maupun mengingatnya) dengan detail tertentu (simbol, gambar, dan lainlain) dalam melakukan pembelian.

Dalam keputusan pembelian konsumen, kesadaran merek juga berperan penting, karena suatu merek yang gampang diingat dan melekat pada ingatan konsumen akan berpengaruh terhadap pembelian kembali terhadap produk tersebut. Sehingga diharapkan perusahaan menunjukkan suatu standar kualitas tertentu untuk memperoleh angka penjualan dan menguasai pasar yang lebih besar. Oleh sebab itu, meraih kesadaran konsumen merupakan salah satu sasaran pemasaran yang perlu dibidik oleh perusahaan. Untuk menimbulkan kesadaran merek pada konsumen dibutuhkan suatu stimulus atau hal-hal yang dapat merangsang munculnya kesadaran merek tersebut. Salah satu cara untuk mendapatkan kesadaran merek konsumen yaitu dengan melakukan kegiatan promosi.

Dalam hal promosi CV.Panda Bakery masih kurang melakukan promosi ke perantara dan konsumen, dimana perusahaan jarang memberikan harga khusus kepada konsumen, kurang memberikan penghargaan bagi konsumen yang setia dan diskon bagi produk tertentu. Sementara setiap konsumen sebelum memutuskan untuk membeli pasti terlebih dahulu melakukan perbandingan dengan perusahaan pesaing yang sejenis. Hal tersebut berakibat pada beberapa konsumen perusahaan memutuskan untuk tidak melakukan pembelian produk dalam jumlah yang banyak, bahkan memutuskan untuk tidak membeli sama sekali.

Berikut adalah Tabel 1.1 mengenai total penjualan di CV.Panda Bakery :

Tabel 1.1

Tabel Total Penjualan di CV.Panda Bakery

\begin{tabular}{|c|l|}
\hline Tahun & \multicolumn{1}{|c|}{$\begin{array}{c}\text { Total } \\
\text { Penjualan }\end{array}$} \\
\hline 2012 & $\begin{array}{l}4.320 .000 \\
\text { bungkus }\end{array}$ \\
\hline 2013 & 3.168 .000 \\
\hline
\end{tabular}

\begin{tabular}{|l|l|}
\hline & bungkus \\
\hline 2014 & $\begin{array}{l}2.592 .000 \\
\text { bungkus }\end{array}$ \\
\hline
\end{tabular}

Sumber : CV.Panda Bakery (2014

Berdasarkan latar belakang yang telah diuraikan diatas dapat diketahui bahwa betapa pentingnya kesadaran merek dan promosi untuk perluasan pangsa pasar dan mencegah penurunan jumlah konsumen, maka penulisan merasa tertarik untuk melihat dan menganalisis tentang: Pengaruh Kesadaran Merek dan Promosi terhadap Keputusan Konsumen untuk membeli di CV.Panda Bakery.

\section{KAJIAN LITERATUR DAN PENGEMBANGAN HIPOTESIS}

\section{Kesadaran Merek (Brand Awareness)}

Brand awareness (kesadaran merek), menunjukan kesanggupan seorang calon pembeli untuk mengenali atau mengingat kembali bahwa suatu merek merupakan bagian dari kategori produk tertentu (Durianto dkk, 2001).

Kesadaran merek berada pada rentang antara perasaan yakin bahwa produk tersebut merupakan satu-satunya dalam kelas produk yang bersangkutan. Rentang ini dapat dibagi menjadi tiga, yaitu pengenalan merek, brand recall, dan top of mind. Pengenalan merek adalah tingkat minimal dari brand awareness yang diperoleh dari pengingatan kembali melalui bantuan. Brand recall diperoleh dengan pengingatan kembali sebuah merek dalam suatu kelas produk tanpa bantuan. Dalam tugas pengingatan kembali sebuah merek, merek yang pertama kali disebutkan berarti merek yang meraih top-of-mind-awareness. Jika suatu merek menjadi satu-satunya merek yang diingat oleh responden, berarti merek tersebut memiliki awareness yang tinggi dan disebut dominant brand (Susanto dan Wijanarko, 2004).

Kesadaran merek (brand awareness) dihubungkan pada kuatnya kesan yang tersimpan dalam memori yang direflesikan pada kemampuan pelanggan untuk mengingat kembali atau mengenali kembali sebuah merek di dalam kondisi yang berbeda. Kesadaran merek (brand awareness) dapat dikarakteristikkan menurut kedalam dan keluasannya. Kedalam dari 
kesadaran merek (brand awareness) berhubungan dengan kemungkinan sebuah merek dapat diingat atau dikenali kembali. Keluasan dari kesadaran merek (brand a waraness) berhubungan dengan keanekaragaman situasi pembelian dan konsumsi di mana sebuah merek diingat (Keller, 2003).

\section{Promosi}

Promosi merupakan aspek yang sangat penting di dalam pemasaran. Tanpa adanya promosi, kegiatan pemasaran akan mengalami hambatan yang akan merugikan perusahaan. Pentingnya promosi berkaitan dengan fungsinya sebagai media komunikasi yang menghubungkan antara perusahaan dengan calon pelanggannya.

Aktifitas promosi ini dapat kita lihat dalam kehidupan sehari-hari, baik yang disadari maupun yang tidak disadari mulai dari spanduk yang dipasang dipinggir jalan, selebaran-selebaran yang diletakkan di pohon atau dinding, iklan televisi yang semakin kreatif dari hari ke hari, dan masih banyak hal lain menyangkut promosi terbesar di sekeliling kita. Kondisi tersebut menyebabkan manusia saat ini dibanjiri oleh banyaknya produk dan juga promosi yang dilakukan oleh perusahaan harus mampu mengkomunikasikan produknya dengan baik untuk dapat menghadapi persaingan atau bahkan memenangkan persaingan tersebut.

Menurut Kotler dan Armstrong (2010), promosi adalah sebuah aktivitas yang mengkomunikasikan hubungan antara produk dengan target konsumen yang akan membeli produk tersebut.

Menurut Peter dan Olson (2000), promosi digunakan untuk menciptakan dan memelihara keunggulan sebuah produk sebagai pembeda dari apa yang ditawarkan pesaing.

Kebijakan promosi suatu perusahaan dapat digunakan untuk memperbesar volume dan melakukan perluasan pasar yang baru, tetapi kegiatan promosi itu memerlukan biaya yang tidak kecil. Oleh sebab itu, setiap perusahaan harus dapat melakukan pemilihan media yang tepat dan berbiaya optimal. Kebijakan promosi merupakan salah satu bagian dari marketing mix yang dipergunakan untuk meladeni konsumen.

\section{Keputusan Pembelian}

Pengertian keputusan pembelian menurut Helga Drumond (2003:68) adalah mengidentifikasikan semua pilihan yang mungkin untuk memecahkan persoalan itu dan menilai pilihan-pilihan serta sistematis dan obyektif serta sasaran-sasarannya yang menentukan keuntungan serta kerugiannya masing-masing.

Pengambilan keputusan merupakan suatu kegiatan individu yang secara langsung terlibat dalam mendapatkan dan mempergunakan barang yang ditawarkan. Tahap-tahap proses keputusan pembelian (Philip Kotler, 2005:204) :

1. Pengenalan Masalah (Problem Recognition)

Proses pembeli dimulai dengan pengenalan masalah atau kebutuhan. Pembeli menyadari suatu perbedaan antara keadaan sebenarnya dan keadaan yang diinginkannya. Kebutuhan itu dapat digerakkan oleh rangsangan dari dalam diri pembeli atau dari luar. Para pemasar perlu mengenal berbagai hal yang dapat menggerakkan kebutuhan atau minat tertentu dalam konsumen. Para pemasar perlu meneliti konsumen untuk memperoleh jawaban, apakah kebutuhan yang dirasakan atau masalah yang timbul, apa yang menyebabkan semua itu muncul, dan bagaimana kebutuhan atau masalah itu menyebabkan seseorang mencari produk tertentu ini.

2. Pencarian Informasi

Seorang konsumen yang mulai terugah minatnya mungkin akan atau mungkin tidak mencari informasi yang lebih banyak lagi. Jika dorongan konsumen adalah kuat, dan obyek yang dapat memuaskan kebutuhan ini tersedia, konsumen akan membeli obyek itu. Jika tidak, kebutuhan konsumen itu tinggal mengendap dalam ingatannya. 
Konsumen mungkin tidak berusaha untuk memperoleh informasi lebih lanjut atau sangat aktif mencari informasi sehubungan dengan kebutuhan itu.

3. Penilaian Alternatif

Setelah melakukan pencarian informasi sebanyak mungkin tentang banyak hal, selanjutnya konsumen harus melakukan penilaian tentang beberapa alternative yang ada dan menentukan langkah selanjutnya. Penilaian ini tidak dapat dipisahkan dari pengaruh sumbersumber yang dimiliki oleh konsumen (waktu, uang dan informasi) maupun resiko keliru dalam penilaian.

4. Keputusan Membeli

Setelah tahap-tahap awal tadi dilakukan, sekarang tiba saatnya bagi pembelian untuk menentukan pengambilan keputusan apakah jadi membeli atau tidak. Jika keputusan menyangkut jenis produk, bentuk produk, merek, penjual, kualitas dan sebagainya.

Untuk setiap pembelian ini, perusahaan atau pemasar perlu mengetahui jawaban atas pertanyaan yang menyangkut perilaku konsumen, misalnya : berapa banyak usaha yang harus dilakukan oleh konsumen dalam pemilihan penjualan (motif langganan/patronage motive), faktor-faktor apakah yang menentukan kesan terhadap sebuah toko, dan motif langganan yang sering menjadi latar belakang pembelian konsumen.

5. Perilaku Setelah Pembelian

Setelah membeli suatu produk, konsumen akan mengalami beberapa tingkatan kepuasan atau tidak ada kepuasan, ada kemungkinan bahwa pembeli memiliki ketidakpuasan setelah melakukan pembelian, karena mungkin harga barang dianggap terlalu mahal, atau mungkin karena tidak sesuai dengan keinginan atau gambaran sebelumnya dan sebagainya. Untuk mencapai keharmonisan dan meminimumkan ketidakpuasan pembeli harus mengurangi keinginan-keinginan lain sesudah pembelian, atau juga pembeli harus mengeluarkan waktu lebih banyak lagi untuk melakukan evaluasi sebelum membeli.

\begin{tabular}{|c|c|c|}
\hline No & $\begin{array}{l}\text { Nama } \\
\text { Peneliti }\end{array}$ & $\begin{array}{l}\text { Reza Ryandi } \\
\text { Aditya (2011) }\end{array}$ \\
\hline 1. & $\begin{array}{l}\text { Alat } \\
\text { Analisis } \\
\text { Hasil } \\
\text { Penelitian }\end{array}$ & $\begin{array}{l}\text { Analisis } \\
\text { Pengaruh } \\
\text { Kesadaran } \\
\text { Merek, } \\
\text { Keragaman } \\
\text { Menu, Promosi } \\
\text { dan Kualitas } \\
\text { Pelayanan } \\
\text { terhadap } \\
\text { Keputusan } \\
\text { Konsumen } \\
\text { untuk membeli } \\
\text { Pizza Hut DP } \\
\text { Mall Semarang } \\
\text { Regresi Linear } \\
\text { Berganda } \\
\text { Hasil } \\
\text { menunjukkan } \\
\text { bahwa harga, } \\
\text { lokasi, } \\
\text { pelayanan, } \\
\text { kesadaran } \\
\text { merek dan } \\
\text { promosi Pizza } \\
\text { Hut DP Mall } \\
\text { Semarang } \\
\text { secara umum } \\
\text { sudah cukup } \\
\text { baik meskipun } \\
\text { dalam } \\
\text { beberapa hal } \\
\text { masih kurang } \\
\text { untuk } \\
\text { memenuhi } \\
\text { harapan } \\
\text { konsumen }\end{array}$ \\
\hline 2. & $\begin{array}{l}\text { Nama } \\
\text { Peneliti }\end{array}$ & $\begin{array}{ll}\text { Emma } & \text { K } \\
\text { MacDonal } & \\
(2000) & \\
\end{array}$ \\
\hline & $\begin{array}{l}\text { Judul } \\
\text { Penelitian } \\
\text { Alat } \\
\text { Analisis } \\
\text { Hasil } \\
\text { Penelitian }\end{array}$ & $\begin{array}{l}\text { Pengaruh } \\
\text { kesadaran } \\
\text { merek pada } \\
\text { pengambilan } \\
\text { keputusan } \\
\text { untuk } \\
\text { pembelian } \\
\text { produk ulang }\end{array}$ \\
\hline
\end{tabular}




\begin{tabular}{|c|c|c|}
\hline & & $\begin{array}{l}\text { Regresi Linear } \\
\text { Berganda } \\
\text { Hasil } \\
\text { penelitian } \\
\text { menunjukkan } \\
\text { bahwa Brand } \\
\text { Awareness } \\
\text { merupakan } \\
\text { bagian penting } \\
\text { dalam } \\
\text { pemilihan } \\
\text { produk oleh } \\
\text { konsumen }\end{array}$ \\
\hline 3. & $\begin{array}{l}\text { Nama } \\
\text { Peneliti }\end{array}$ & $\begin{array}{l}\text { K.Jusuf } \\
\text { (2010) }\end{array}$ \\
\hline & $\begin{array}{l}\text { Judul } \\
\text { Penelitian } \\
\text { Alat } \\
\text { Analisis } \\
\text { Hasil } \\
\text { Penelitian }\end{array}$ & $\begin{array}{l}\text { Analisa } \\
\text { Pengaruh } \\
\text { Promosi } \\
\text { Penjualan dan } \\
\text { Loyalitas } \\
\text { Merek } \\
\text { terhadap } \\
\text { Keputusan } \\
\text { Pembelian } \\
\text { Konsumen } \\
\text { Regresi Linear } \\
\text { Berganda } \\
\text { Hasil } \\
\text { penelitian } \\
\text { menunjukkan } \\
\text { bahwa promosi } \\
\text { penjualan } \\
\text { mempengaruhi } \\
\text { secara } \\
\text { signifikan } \\
\text { terhadap } \\
\text { keputusan } \\
\text { pembelian } \\
\text { konsumen }\end{array}$ \\
\hline 4. & $\begin{array}{l}\text { Nama } \\
\text { Peneliti }\end{array}$ & Gita (2009) \\
\hline & $\begin{array}{l}\text { Alat } \\
\text { Analisis } \\
\text { Hasil } \\
\text { Penelitian }\end{array}$ & $\begin{array}{l}\text { Pengaruh } \\
\text { Kesadaran } \\
\text { Merek, } \\
\text { Persepsi } \\
\text { Kualitas, } \\
\text { Asosiasi } \\
\text { Merek dan } \\
\text { Loyalitas } \\
\text { Merek } \\
\text { terhadap }\end{array}$ \\
\hline
\end{tabular}

\begin{tabular}{|c|c|c|}
\hline & & $\begin{array}{l}\text { Ekuitas Merek } \\
\text { restoran cepat } \\
\text { saji } \\
\text { McDonalds' } \\
\text { Citraland } \\
\text { Semarang } \\
\text { Regresi Linear } \\
\text { Berganda } \\
\text { Hasil } \\
\text { penelitian } \\
\text { tersebut } \\
\text { menyimpulkan } \\
\text { bahwa } \\
\text { kesadaran } \\
\text { merek } \\
\text { berpengaruh } \\
\text { positif dan } \\
\text { signifikan } \\
\text { terhadap } \\
\text { keputusan } \\
\text { konsumen. } \\
\text { Kesadaran } \\
\text { seseorang yang } \\
\text { besar atas } \\
\text { suatu merek } \\
\text { akan menciptakan } \\
\text { keinginan } \\
\text { untuk selalu } \\
\text { dapat memiliki } \\
\text { merek tersebut } \\
\text { sebagai bagian } \\
\text { dari yang } \\
\text { dimiliki } \\
\text { seseorang. }\end{array}$ \\
\hline 5. & $\begin{array}{l}\text { Nama } \\
\text { Peneliti }\end{array}$ & $\begin{array}{l}\text { Soni Neha dan } \\
\text { Veghese } \\
\text { Manoj (2013) }\end{array}$ \\
\hline & $\begin{array}{l}\text { Judul } \\
\text { Penelitian } \\
\text { Alat } \\
\text { Analisis } \\
\text { Hasil } \\
\text { Penelitian }\end{array}$ & $\begin{array}{l}\text { Dampak dari } \\
\text { alat promosi } \\
\text { penjualan } \\
\text { terhadap } \\
\text { keputusan } \\
\text { pembelian } \\
\text { konsumen } \\
\text { pada produk } \\
\text { "white good" } \\
\text { at Durg and } \\
\text { Bhilai Region } \\
\text { of CG, India } \\
\text { Regresi Linear }\end{array}$ \\
\hline
\end{tabular}




\begin{tabular}{|l|l|}
\hline & Berganda \\
Alat promosi \\
penjualan \\
memiliki \\
pengaruh yang \\
signifikan \\
terhadap \\
keputusan \\
pembelian \\
konsumen \\
pada produk \\
"white good" \\
(kulkas)
\end{tabular}

\section{Kerangka Konseptual}

Kerangka pikir adalah kerangka mengenai konsep masalah yang sedang dibahas agar penelitian menjelaskan konsep yang dipakai agar terjadi pemahaman yang sama antara peneliti dan pembaca penelitian.

Kesadaran merek (brand awareness) adalah kemampuan seorang konsumen untuk mengidentifikasikan suatu merek (baik mengenal maupun mengingatnya) dengan detail tertentu (simbol, suara, gambar, dan lain-lain) dalam melakukan pembelian.

Promosi adalah Upaya untuk memberikan atau menawarkan produk atau jasa dengan tujuan menarik calon konsumen untuk membeli atau mengkonsumsinya.

Keputusan konsumen adalah Keputusan pembelian tentang merek mana yang dibeli.

Dari beberapa teori yang dikemukakan, dapat diungkapkan suatu kerangka berpikir yang berfungsi sebagai penuntun alur pikir dan dasar penelitian ini yang dapat digambarkan sebagai berikut :

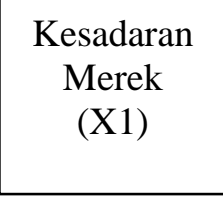

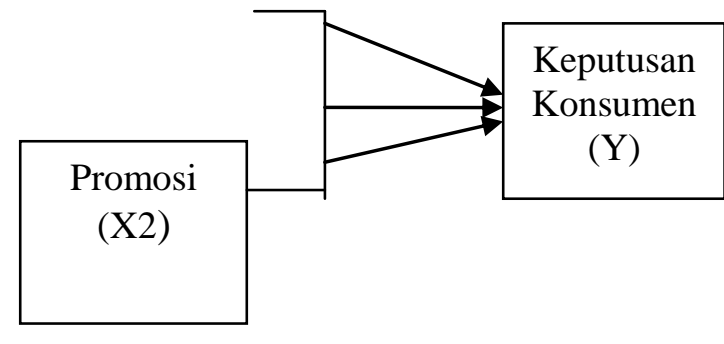

Gambar 1.1

Kerangka Konseptual

\section{Hipotesis}

Hipotesis merupakan jawaban sementara terhadap rumusan masalah penelitian, dimana rumusan masalah penelitian telah dinyatakan dalam bentuk pertanyaan (Sugiyono 2009:29). Berdasarkan uraian pada latar belakang masalah, penelitian terdahulu, dan landasan teori, maka penulisan mengajukan hipotesis sebagai berikut : Penelitian Emma K MacDonal (2000) menyatakan bahwa brand awareness merupakan bagian penting dalam pemilihan produk oleh konsumen. Gita (2009) menyimpulkan bahwa kesadaran merek berpengaruh positif dan signifikan terhadap keputusan konsumen. Kesadaran seseorang yang besar atas suatu merek akan menciptakan keinginan untuk selalu dapat memiliki merek tersebut sebagai bagian dari yang dimiliki seseorang. Berdasarkan penjelasan diatas, diajukan hipotesis 1 sebagai berikut:

H1 : Kesadaran merek berpengaruh terhadap keputusan konsumen untuk membeli di CV.Panda Bakery.

Pada penelitian sebelumnya, dikatakan bahwa promosi penjualan mempengaruhi secara signifikan terhadap keputusan pembelian konsumen (K.Jusuf 2010). Berdasarkan pernyataan ini, maka hipotesis 2 dalam penelitian ini dirumuskan sebagai berikut :

H2 : Promosi berpengaruh terhadap keputusan konsumen untuk membeli di CV.Panda Bakery.

Pada penelitian yang lalu, Reza Ryandi Aditya (2011) mengatakan bahwa harga, lokasi, pelayanan, kesadaran merek dan promosi Pizza Hut DP Mall Semarang secara umum sudah cukup baik meskipun dalam beberapa hal masih kurang untuk memenuhi harapan konsumen. Soni Neha dan Veghese Manoj (2013) 
mengatakan bahwa alat promosi penjualan memiliki pengaruh yang signifikan terhadap keputusan pembelian konsumen pada produk "white good" (kulkas). Berdasarkan penjelasan diatas, diajukan hipotesis 3 sebagai berikut :

H3 : Kesadaran merek dan promosi berpengaruh terhadap keputusan konsumen untuk membeli di CV.Panda Bakery

\section{METODE PENELITIAN}

\section{Metode Yang Digunakan}

Metode penelitian yang digunakan adalah metode deskriptif kuantitatif. Sugiono (2009:14) menyatakan bahwa "Metode penelitian kuantitatif dapat diartikan sebagai metode penelitian yang berlandaskan pada filsafat positivisme, digunakan untuk meneliti pada populasi atau sampel tertentu, teknik pengambilan sampel pada umumnya dilakukan secara random, pengumpulan data menggunakan instrumen penelitian, analisis data bersifat kuantitatif/statistik dengan tujuan untuk menguji hipotesis yang telah ditetapkan".

Menurut Azwar (2007:5) "bahwa metode analisis kuantitatif adalah menekankan analisisnya pada data-data angaka yang diolah dengan metode statistika".

\section{Jenis dan Sumber Data Penelitian}

Dalam penelitian yang dilakukan, penulis mempergunakan dua jenis data untuk membantu memecahkan masalah :

a. Data Kualitatif

Data kualitatif adalah data yang berbentuk kata-kata, bukan dalam bentuk angka. Data kualitatif diperoleh melalui berbagai macam teknik pengumpulan data misalnya wawancara, analisis dokumen, diskusi terfokus, atau observasi yang teah dituangkan dalam catatan lapangan (transkrip). Bentuk lain data kualitatif adalah gambar yang diperoleh melalui pemotretan atau rekaman video.

b. Data Kuantitatif

Data kuantitatif adalah metode yang digunakan untuk menyajikan data dalam bentuk angka. Sesuai dengan bentuknya, data kuantitatif dapat diolah atau dianalisis menggunakan teknik perhitungan matematika atau statistika.
Selain itu, sumber data yang digunakan dalam penelitian ini yaitu:

a. Data primer : data yang dikumpulkan sendiri oleh peneliti langsung dari sumber pertama.

b. Data sekunder : data yang diterbitkan atau digunakan oleh organisasi yang bukan pengelolanya.

\section{Populasi dan Sampel Penelitian}

Populasi adalah sekelompok keseluruhan orang, peristiwa atau sesuatu yang ingin diselidiki oleh peneliti (Sri Sularso, 2003:67). Berdasarkan pendapat tersebut yang menjadi populasi dalam penelitian ini adalah total pelanggan toko pada CV.Panda Bakery tahun 2014 sebanyak 80 toko.

Sampel adalah beberapa anggota atau bagian yang dipilih dari populasi. Dengan mempelajari sampel penelitian berharap dapat mengambil kesimpulan yang akan digeneralisasikan keseluruhan populasi (Sri Sularso, 2003:67). Apabila subjek kurang dari 100, sampel lebih baik diambil semua. selanjutna jika subjeknya lebih besar dari 100, maka sampel dapat diambil antara $10-15 \%$ atau $20-25 \%$ atau lebih. Karena subjek dalam penelitian ini kurang dari 100, maka sampel diatas penelitian ini diambil semua sejumlah 80 toko.

\section{Definisi Operasional Variabel Penelitian}

Adapun definisi, indikator dan pengukuran variabel dapat dilihat pada tabel berikut :

Tabel 1.3

\section{Operasional Variabel Penelitian}

\begin{tabular}{|l|l|l|c|}
\hline Variabel & $\begin{array}{c}\text { Definisi } \\
\text { Operasio } \\
\text { nal }\end{array}$ & Indikator & $\begin{array}{c}\text { Penguk } \\
\text { uran }\end{array}$ \\
\hline $\begin{array}{l}\text { Kesadaran } \\
\text { Merek }\end{array}$ & $\begin{array}{l}\text { Kemamp } \\
\text { uan }\end{array}$ & $\begin{array}{l}\text { Unware } \\
\text { of brand }\end{array}$ & Likert \\
& seorang & Brand & \\
& konsume & recogniti & \\
& n untuk & on & \\
& mengiden & Brand & \\
& tifikasika & recall & \\
& n suatu & Top of & \\
\hline
\end{tabular}




\begin{tabular}{|c|c|c|c|}
\hline & $\begin{array}{l}\text { merek } \\
\text { (baik } \\
\text { mengenal } \\
\text { maupun } \\
\text { menginga } \\
\text { tnya) } \\
\text { dengan } \\
\text { detail } \\
\text { tertentu } \\
\text { (simbol, } \\
\text { suara, } \\
\text { gambar, } \\
\text { dan lain- } \\
\text { lain) } \\
\text { dalam } \\
\text { melakuka } \\
\text { n } \\
\text { pembelia } \\
\text { n. }\end{array}$ & mind & \\
\hline $\begin{array}{l}\text { Promosi } \\
(\mathrm{X} 2)\end{array}$ & $\begin{array}{l}\text { Upaya } \\
\text { untuk } \\
\text { memberi } \\
\text { kan atau } \\
\text { menawar } \\
\text { kan } \\
\text { produk } \\
\text { atau jasa } \\
\text { dengan } \\
\text { tujuan } \\
\text { menarik } \\
\text { calon } \\
\text { konsume } \\
\text { n untuk } \\
\text { membeli } \\
\text { atau } \\
\text { mengkon } \\
\text { sumsinya. }\end{array}$ & $\begin{array}{l}\text { Diskon } \\
\text { Imbalan } \\
\text { kesetiaan } \\
\text { Harga } \\
\text { khusus } \\
\text { Kontes, } \\
\text { undian } \\
\text { dan } \\
\text { permaina } \\
\text { n }\end{array}$ & Likert \\
\hline
\end{tabular}

\begin{tabular}{|c|c|c|c|}
\hline $\begin{array}{l}\text { Keputusa } \\
\text { n } \\
\text { Konsume } \\
\text { n (Y) }\end{array}$ & $\begin{array}{l}\text { Keputusa } \\
\mathrm{n} \\
\text { pembelia } \\
\mathrm{n} \text { tentang } \\
\text { merek } \\
\text { mana } \\
\text { yang } \\
\text { dibeli. }\end{array}$ & $\begin{array}{l}\text { Keputusa } \\
\mathrm{n} \text { tentang } \\
\text { merek } \\
\text { produk } \\
\text { Keputusa } \\
\mathrm{n} \text { tentang } \\
\text { model/be } \\
\text { ntuk } \\
\text { produk } \\
\text { Keputusa } \\
\text { n tentang } \\
\text { jumlah } \\
\text { produk } \\
\text { Keputusa } \\
\text { n tentang } \\
\text { jenis } \\
\text { produk } \\
\text { Keputusa } \\
\text { n tentang } \\
\text { cara } \\
\text { pembaya } \\
\text { ran }\end{array}$ & Likert \\
\hline
\end{tabular}

Sumber : Hasil Penelitian

\section{HASIL DAN PEMBAHASAN}

\section{Hasil Uji Determinasi}

Nilai Adjusted $R$ Square $\left(\mathrm{R}^{2}\right)$ atau koefisien determinasi digunakan untuk mengetahui seberapa besarnya kontribusi dari variabel bebas yang berpengaruh terhadap variabel terikat, dan sisanya dipengaruhi oleh variabel bebas lainnya yang tidak dimasukkan ke dalam model.

\section{Tabel 1.4. Uji Determinasi}

\begin{tabular}{|c|c|c|}
\hline $\begin{array}{c}\mathrm{R} \\
\text { Square }\end{array}$ & $\begin{array}{c}\text { Adjusted } \\
R \\
\text { Square }\end{array}$ & $\begin{array}{c}\text { Std. } \\
\text { Error of } \\
\text { the } \\
\text { Estimate }\end{array}$ \\
\hline Sumber $:$ Hasil & Penelitian, 2015 (Data
\end{tabular}

Diolah)

Hasil penelitian ini menunjukkan bahwa nilai (Adjusted $R^{2}$ ) adalah 0,513 atau 51,3\%. Artinya keputusan konsumen untuk membeli di CV.Panda Bakery dapat dijelaskan oleh kesadaran merek dan promosi. Sedangkan 
sisanya sebesar 0,487 atau 48,7\% dijelaskan oleh sebab-sebab yang lain seperti saluran distribusi dan produk.

\section{Hasil Uji t}

Pengujian ini dilakukan untuk mengetahui seberapa jauh pengaruh satu variabel independen secara parsial (individual) menerangkan variasi variabel independen.

Tabel 1.5 Uji t

\begin{tabular}{|l|l|c|c|}
\hline & \multicolumn{1}{|c|}{ Model } & $\mathrm{t}$ & $\mathrm{Sig}$ \\
\hline 1 & (Constant) & 2.368 & .020 \\
& Kesadaran & 3.029 & .003 \\
& Merek & 8.440 & .000 \\
& Promosi & & \\
\hline
\end{tabular}

Sumber : Hasil Penelitian, 2015 (Data Diolah)

Dilihat bahwa variabel kesadaran merek mempunyai probabilitas tingkat kesalahan 0,003 lebih kecil dari tingkat signifikansi 0,05 dan nilai $t_{\text {hitung }}(3,029)>t_{\text {tabel }}(1,991)$. Dengan demikian, maka $\mathrm{H}_{1}$ diterima. Hal ini berarti variabel kesadaran merek secara parsial mempunyai pengaruh yang signifikan terhadap keputusan konsumen untuk membeli di CV.Panda Bakery.

Dilihat bahwa variabel promosi mempunyai probabilitas tingkat kesalahan 0,000 lebih kecil dari tingkat signifikansi 0,05 dan nilai $t_{\text {hitung }}$ $(8,440)>t_{\text {tabel }}(1,991)$. Dengan demikian maka $\mathrm{H}_{2}$ diterima. Hal ini berate variabel promosi secara parsial mempunyai pengaruh yang signifikan terhadap keputusan konsumen untuk membeli di CV.Panda Bakery.

\section{Hasil Uji F}

Pengujian ini dilakukan untuk melihat secara besama-sama pengaruh atau hubungan positif dan signifikan variabel bebas $\left(\mathrm{X}_{1}\right.$ dan $\left.\mathrm{X}_{2}\right)$ berupa variabel kesadaran merek, promosi terhadap variabel terikat $(\mathrm{Y})$ berupa keputusan konsumen.

Tabel 1.6 Uji F

\begin{tabular}{|c|r|r|r|}
\hline Model & $\begin{array}{c}\text { Mean } \\
\text { Square }\end{array}$ & F & Sig. \\
\hline 1 & 167.79 & 42.55 & .000 \\
Regressio & 7 & 7 & a \\
\hline
\end{tabular}

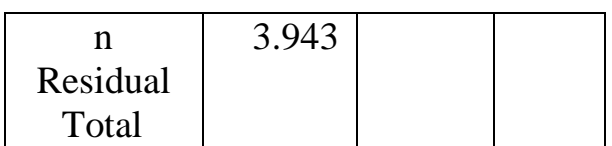

Sumber : Hasil Penelitian, 2015 (Data Diolah)

Berdasarkan nilai $\mathrm{F}_{\text {hitung }}(42,557)>\mathrm{F}_{\text {tabel }}$ (3,115), maka dapat disimpulkan bahwa variabel bebas yaitu $\left(\mathrm{X}_{1}\right.$ dan $\left.\mathrm{X}_{2}\right)$ berupa kesadaran merek dan promosi berpengaruh secara bersama atau simultan terhadap variabel terikat (Y) keputusan konsumen untuk membeli di CV.Panda Bakery.

\section{Hasil Model Regresi Linear Berganda}

Variabel independen yang terdiri dari kesadaran merek dan promosi memiliki pengaruh terhadap keputusan konsumen untuk membeli di CV.Panda Bakery. Dari hasil pengolahan data dengan menggunakan SPSS 18 for Windows diperoleh hasil sebagai berikut.

Tabel 1.7. Regresi Linear Berganda

\begin{tabular}{|l|c|c|c|}
\hline \multirow{2}{*}{ Model } & \multicolumn{2}{|c|}{$\begin{array}{c}\text { Unstandardized } \\
\text { Coefficients }\end{array}$} & $\begin{array}{c}\text { Standardized } \\
\text { Coefficients }\end{array}$ \\
\cline { 2 - 4 } & $\mathrm{B}$ & $\begin{array}{c}\text { Std.Err } \\
\text { or }\end{array}$ & Beta \\
\hline $1 \quad$ (Constant) & 4.476 & 1.890 & \\
Kesadaran Merek & .316 & .104 & .239 \\
Promosi & .649 & .077 & .665 \\
& & & \\
\hline
\end{tabular}

Sumber : Hasil Penelitian, 2015 (Data Diolah)

Diperoleh persamaan regresi linear berganda sebagai berikut:

$$
\mathrm{Y}=4,476+0,316 \mathrm{X}_{1}+0,649 \mathrm{X}_{2}+\mathrm{e}
$$

1. Nilai konstanta $\alpha(4,476)$, artinya, jika kesadaran merek dan promosi bernilai 0 , maka keputusan konsumen pada CV.Panda Bakery adalah sebesar 4,476 satu-satuan.

2. Nilai koefisien $\beta_{1}(0,316)$, artinya jika kesadaran merek ditingkatkan, maka keputusan konsumen akan mengalami peningkatan sebesar 0,316 satu-satuan.

3. Nilai koefisien $\beta_{2}(0,649)$, artinya jika promosi ditingkatkan sebesar satu-satuan, maka keputusan konsumen akan mengalami peningkatan sebesar 0,649 satu-satuan.

\section{PEMBAHASAN}

Berdasarkan penelitian terdahulu dari Emma K MacDonald (2000) terdapatkan kesamaan 
antara variabel kesadaran merek yang secara parsial dan signifikan berpengaruh terhadap keputusan konsumen untuk pembelian produk ulang. Kemudian pada penelitian terdahulu K.Jusuf (2010) terdapat kesamaan antara variabel promosi yang secara positif dan signifikan berpengaruh terhadap keputusan pembelian konsumen. Dan pada penelitian terdahulu Reza Ryandi Aditya (2011) juga terdapat kesamaan variabel kesadaran merek dan promosi yang secara positif dan signifikan berpengaruh terhadap keputusan konsumen untuk membeli di Pizza Hut DP Mall Semarang.

Jika dibandingkan dengan penelitian terdahulu diatas terdapat kesamaan variabel kesadaran merek dan promosi terhadap keputusan konsumen untuk membeli. Sehingga variabel kesadaran merek dan promosi dapat dikatakan berpengaruh terhadap keputusan konsumen untuk membeli di CV.Panda Bakery.

\section{KESIMPULAN DAN SARAN}

\section{Kesimpulan}

Berdasarkan hasil analisis yang telah dibahas pada bab terdahulu, maka dapat ditarik kesimpulan sebagai berikut :

1. Secara parsial ditunjukkan bahwa variabel kesadaran merek berpengaruh secara positif dan signifikan terhadap keputusan konsumen untuk membeli CV.Panda Bakery.

2. Secara parsial ditunjukkan bahwa variabel promosi berpengaruh positif dan signifikan terhadap keputusan konsumen untuk membeli di CV.Panda Bakery.

3. Secara simultan ditunjukkan bahwa variabel independen (kesadaran merek dan promosi) berpengaruh secara positif dan signifikan terhadap keputusan konsumen untuk membeli di CV.Panda Bakery.

4. Berdasarkan perhitungan koefisien determinasi, maka diperoleh nilai Adjusted $\mathrm{R}$ Square sebesar 0,513 angka ini menjelaskan bahwa sebesar 51,3\% keputusan konsumen untuk membeli di CV.Panda Bakery dapat dijelaskan oleh variabel kesadaran merek dan promosi. Proporsi dari nilai ini dapr dikatakan kuat dan sisanya sebesar $48,7 \%$ dipengaruhi oleh faktor-faktor lain yang tidak dijelaskan dalam penelitian ini.

\section{Saran}

Saran yang dapat dikemukakan penulis berdasarkan hasil penelitian adalah :

1. Pada variabel kesadaran merek yang harus ditingkatkan adalah kemampuan mengenali merek dan kemampuan mengingat merek tanpa harus diingatkan kembali. Dan yang harus di pertahankan adalah usaha untuk menyadari merek dan kemampuan merek produk yang pertama kali muncul di benak pelanggan.

2. Pada variabel promosi yang harus ditingkatkan adalah usaha untuk memberikan diskon dan usaha memberikan peluang kepada pelanggan untuk memenangkan sesuatu. Dan yang harus dipertahankan adalah usaha mendapatkan hadiah kepada pelanggan yang setia dan usaha memberi harga khusus berupa kemasan tunggal yang dijual dengan harga murah.

3. Pada variabel keputusan konsumen yang harus ditingkatkan adalah keputusan tentang model / bentuk produk, keputusan tentang jenis produk dan keputusan tentang cara pembayaran. Dan yang harus dipertahankan adalah keputusan tentang merek produk dan keputusan tentang jumlah produk.

4. Perusahaan disarankan agar memperhatikan faktor-faktor lainnya, yang tidak diteliti dalam penelitian ini, karena berdasarkan hasil penelitian, ada faktor-faktor lainnya yang tutur memberikan dampak yang signifikan terhadap keputusan konsumen seperti harga dan distribusi penjualan.

\section{REFERENSI}

Durianto dkk, 2001. Strategi Menaklukkan Pasar Melalui Riset Ekuitas dan Perilaku Merek. Jakarta: PT.Gramedia Pustaka Utama.

2004. Brand Equity dan Strategi Memimpin Pasar. Jakarta: PT.Gramedia Pustaka Utama.

Drumond, Helga. 2003. Metode Penelitian Bisinis (jilid 1, edisi kelima). Jakarta: Erlangga. 
Emma K MacDonal. 2000. Pengaruh Kesadaran Merek pada Pengambilan Keputusan untuk Pembelian Produk Ulang.

Gita. 2009. Pengaruh Kesadaran Merek, Persepsi Kualitas, Asosiasi Merek dan Loyalitas Merek terhadap Ekuitas Merek Restoran Cepat Daji McDonalds' Citraland Semarang.

Humdiana, 2005. Analisis Elemen-elemen Merek. Jurnal of Marketing Manajemen, vol.2,no.1

K.Jusuf. 2010. Analisis Pengaruh Promosi Penjualan dan Loyalitas Merek terhadap Keputusan Pembelian Konsumen.

Keller, 2003. Manajemen Pemasaran. PT.Indeks, Jakarta.

Kotler, Philip. 2003. Manajemen Pemasaran. Edisi Kesebelas. Jakarta: Indeks kelompok Gramedia.

2005. Manajemen Pemasaran: Analisis, Perencanaan dan Pengendalian (jilid 1). Jakarta: Erlangga.

Kotler dan Amstrong, 2007. Dasar-dasar Pemasaran Edisi Kesembilan Jilid 1, PT.Indeks Jakarta.

Pemasaran Edisi 13. Jakarta: Erlangga. $2008 . \quad$ Manajemen

Kotler, Philip dan Gary Amstrong. 2008. Prinsip-prinsip Pemasaran. Edisi 12 Jilid 1. Jakarta: Erlangga.

Kotler, Philip. 2009. Manajemen Pemasaran, Jilid 9. Jakarta: Erlangga.

Kotler dan Amstrong, 2010. Principle of Marketing (edisi 13). United States of America Pearson.

Lamb, Hair, Mc-Daniel, 2001. Pemasaran. Edisi Pertama, Salemba Empat. Jakarta.
Neha, Soni dan Verhese Manoj. 2013. Dampak dari Alat Promosi Penjualan terhadap Keputusan Pembelian Konsumen pada Produk "White Good" at Durg and Bhilai Region of GG, India.

Peter dan Olson, 2000. Consumer Behavior. Perilaku Konsumen dan Strategi Pemasaran Jidil 1. Edisi Keempat. Jakarta: Erlangga.

Ryandi Aditya, Reza. 2011. Analisis Pengaruh Kesadaran Merek, Keragaman Menu, Promosi dan Kualitas Pelayanan terhadap Keputusan Konsumen untuk Membeli Pizza Hut DP Mall Semarang.

Soehadi, 2005. Effective Branding Konsep dan Aplikasi Pengembangan Merek, Quantum Bisnis dan Manajemen. Bandung.

Sugiyono. 2005. Metode Penelitian Bisnis. Cetakan Pertama. Bandung: Penerbit CV.Alpha Beta.

2008. Metode Penelitian Bisnis. Cetakan Keduabelas. Bandung: Penerbit Alfabeta.

2009. Metode Penelitian Kuantitatif, Kualitatif, Bandung: Alfabeta.

Susanto dan Wijanarko, 2004. Power Branding: Membangun Merek Unggul dan Organisasi Pendukungnya. Jakarta: PT. Mitan Publika Jakarta.

Swastha, 2005. Manajemen Penjualan, Cetakan Keduabelas, Penerbit Liberty. Yogyakarta. 